GRADIATION\&APPLICATIONS

ISSN 2466-4294 (online) | rad-journal.org

Vol. 3 | Issue 1 | pp. 1-6, 2018

doi: 10.21175/RadJ.2018.01.001

Invited review paper

\title{
URANIUM MINING LEGACY AND RADIATION PROTECTION*
}

\author{
Fernando P. Carvalho** \\ Laboratório de Protecção e Segurança Radiológica, Instituto Superior Técnico/ Universidade de Lisboa, \\ Estrada Nacional 10, km 139, 2695-066 Bobadela LRS, Portugal
}

\begin{abstract}
Old uranium and radium production sites in Portugal were investigated to determine concentrations of uranium series radionuclides in mining and milling waste, mine drainage, and in surrounding environment. It was found that the ingestion of horticulture products grown with irrigation water from contaminated wells, combined with radon inhalation and enhanced ambient radiation doses could be the origin of radiation exposure of members of the population exceeding radiation dose limits. Site clean-up and environmental remediation measures were applied in many of those legacy sites, including coverage of tailings, continued treatment of mine water drainage, and removal of contaminated materials. These remediation measures reduced local contamination and the exposure of population to radioactivity, contributing to improved radiation safety. Lessons to retain and procedures currently recommended to avoid generating new uranium legacies are summarized.
\end{abstract}

Key words: Uranium, radium, milling tailings, environmental contamination, radiation doses, environmental remediation

\section{INTRODUCTION}

The exploitation of radium and uranium in Europe during the 2oth century left a legacy of mining sites and milling facilities with radioactive contaminated materials that fall in the scope of the European Basic Safety Standards (BSS) as existing situations of radiation exposure (EU Directive 59/2013). Currently, the former radium and uranium producers are dealing with the environmental remediation of such sites in order to meet the radiation safety requirements of European BSS. This is the case, for example, of Germany, France, Spain, Hungary, and Portugal amongst several other former uranium producing countries [1-3].

In Portugal, uranium and radium production took place mainly in the granite region of the center north of the country where sixty vein deposits of secondary uranium minerals were exploited. Uranium ore milling was carried out in facilities by the mines of Urgeiriça (Canas de Senhorim), Bica (Sabugal), Forte Velho and Barracão (Guarda), Senhora das Fontes (Pinhel), and Casteleiro (Gouveia). After the closure of the last mine and milling facilities in 2001, public concerns about the fate of uranium residues motivated an assessment of environmental contamination and risks to public health posed by such residues (Fig. 1) [4,5].

The environmental investigation allowed identifying the old mining sites and amounts of waste, determining radionuclide concentrations, and revealing situations where environmental dispersal of radionuclides was occurring and leading to the exposure of local populations through water and food consumption, as well as through radon exposure and radioactive dust inhalation [6-8]. Following this radiation risk assessment, the government approved an environmental remediation project for abandoned mines and mining areas areas and, from 2005 up to the present, already about thirty of those former uranium sites have been cleaned and remediated along with other non-radioactive ore mining sites [9]. This environmental remediation programme aims to ensure that radiation exposure from uranium mining legacy to members of the public remains below $1 \mathrm{mSv} / \mathrm{y}$, excluding the natural radiation background, and to protect the environment and non-human biota from contamination by toxic metals and radioactive elements. Environmental radioactivity measurements in soils, water, agriculture products and livestock produced in the region have been performed, and are made annually since 2005 to maintain surveillance over environmental contamination and periodically assess the radiation exposure of humans and biota [8].

A review of the radioactive contamination of these uranium legacy areas, radiation exposure of population, site clean-up, and environmental remediation is presented herein with a description of radiation protection measures implemented. As radiation protection standards are internationally

\footnotetext{
* The paper was presented as an invited lecture at the Fifth International Conference on Radiation and Applications in Various Fields of Research (RAD 2017), Budva, Montenegro, 2017.

carvalho@itn.pt
} 
F. P. Carvalho, Uranium mining legacy and radiation protection, Rad. Applic., 2018, 3, 1, 1-6

harmonized, the case studies described herein and the experience accumulated in the remediation of uranium legacy can be valuable to deal with similar legacy cases elsewhere.

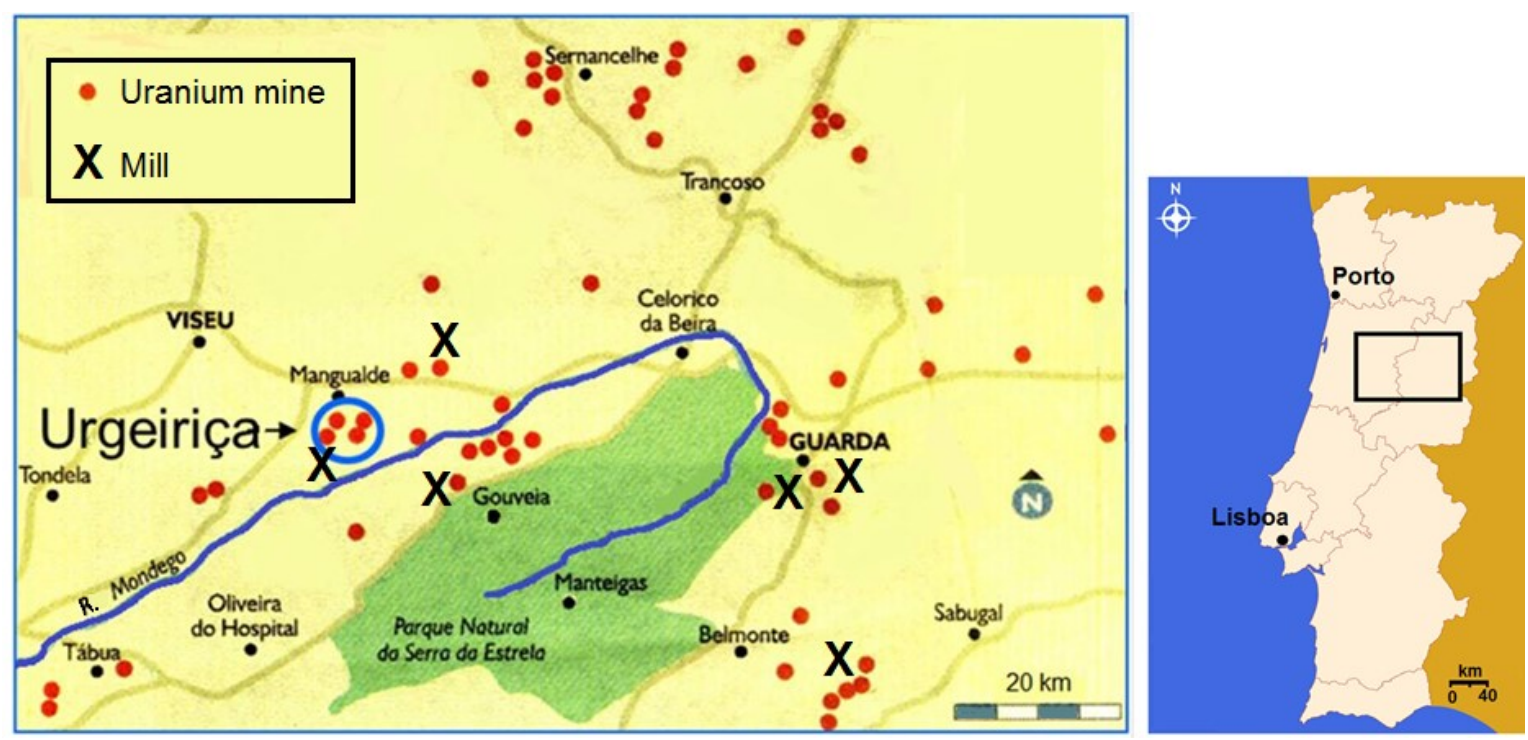

Figure 1. Location of old radium and uranium mines and milling facilities

\section{ASSESSMENT OF HAZARDS FROM URANIUM LEGACY}

All former radium and uranium mine sites in Portugal were listed, identified and visited to determine and map ambient radiation doses, collect samples of radionuclides for analysis in the laboratory, and evaluate the need for environmental remediation measures [6-8].

Samples were analyzed by gamma and alpha spectrometry, by liquid scintillation techniques and inductively coupled plasma-mass spectrometry (ICPMS) in order to determine radionuclide concentrations, particularly those of uranium and thorium families $[6,7,10]$. Radon measurements were performed in surface air outdoors and indoors in dwellings in villages of the mining regions [6,7]. Furthermore, risks of conventional accidents to humans and cattle posed by galleries, open pits, ventilation stacks, waste heaps, landslides, and mine drainage were identified. The potential for the dispersion of waste containing radionuclides into soils, freshwater streams, and groundwater was also assessed [11].

External (ambient) radiation exposure on the milling tailing heaps was $7.5 \mu \mathrm{Gy} / \mathrm{h}$ at Urgeiriça, and $9.5 \mu \mathrm{Gy} / \mathrm{h}$ at Forte Velho mine, well above the natural radiation background of the region, which varies from 0.20 to near $0.80 \mu \mathrm{Gy} / \mathrm{h}$.

Determination of radionuclides in samples from mining and milling waste heaps and also environmental materials from mining areas confirmed high concentrations particularly of ${ }^{238} \mathrm{U}$ daughters, such as ${ }^{230} \mathrm{Th},{ }^{226} \mathrm{Ra},{ }^{210} \mathrm{~Pb}$ and ${ }^{210} \mathrm{Po}$. In the legacy areas, particularly around milling facilities and milling waste heaps, the spread of radioactive contamination in surface soils was recorded. For example, in soils from small farms near the uranium milling facilities of
Cunha Baixa, radionuclide concentrations were as high as $880 \pm 25 \mathrm{~Bq} / \mathrm{kg}$ of ${ }^{238} \mathrm{U}, 1125 \pm 115$ of ${ }^{226} \mathrm{Ra}$ and, $1010 \pm 40 \mathrm{~B} / \mathrm{kg}$ of ${ }^{210} \mathrm{~Pb}$ which were at least one order of magnitude higher than the average concentrations in soils from the the surrounding region.

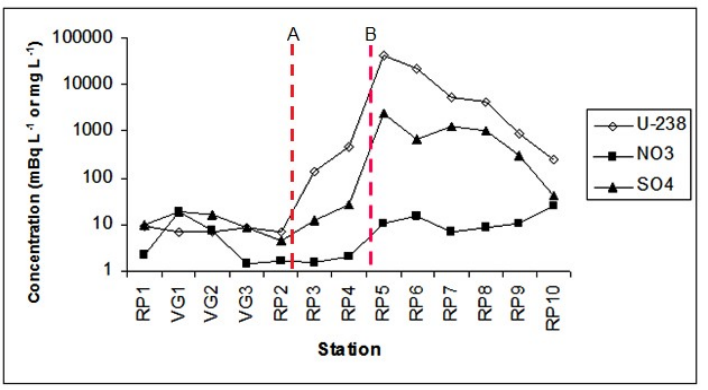

Figure 2. Dissolved uranium-238 concentration $(\mathrm{mBq} / \mathrm{L})$ and major ions (mg/L) in stream water of Ribeira da Pantanha, showing an increase of $U$ and sulphate from uranium leaching downstream discharge points of two mines, A and B (in 2005). Nitrate originates in agriculture.

Radionuclides in mine waters and acidic drainage from milling waste heaps exposed to weathering displayed concentrations of $(23 \pm 1) \times 10^{8} \mathrm{mBq} / \mathrm{L}{ }^{238} \mathrm{U}$, $100 \pm 4 \mathrm{mBq} / \mathrm{L}$ of ${ }^{226} \mathrm{Ra}$, and $176 \pm 9 \mathrm{mBq} / \mathrm{L}{ }^{210} \mathrm{Po}$. This untreated drainage flowing directly into surface streams, such as the Ribeira da Pantanha near Urgeiriça and Ribeira do Castelo near Cunha Baixa, enhanced natural concentrations of radionuclides, such as ${ }^{238} \mathrm{U}$ in surface waters from below $10 \mathrm{mBq} / \mathrm{L}$ up to $10^{5} \mathrm{mBq} / \mathrm{L}$ (Figure 2) [12,13]. In Viseu region, where several old uranium mines were operated, surface streams drained the leached radionuclides and acid mine drainage into the major river in the region, River Mondego. The background levels of these naturally 
F. P. Carvalho, Uranium mining legacy and radiation protection, Rad. Applic., 2018, 3, 1, 1-6

occurring radionuclides in River Mondego were enhanced with the discharges of tributary streams, although radionuclide concentrations at the artificial lake of Aguieira built in the River Mondego, where water is collected to supply drinking water to the region, remained well below the radioactivity limits for drinking water. Radionuclide concentrations, although high in tributaries, decreased due to dilution in River Mondego to values generally below the drinking water guidelines, 1.0 $\mathrm{Bq} / \mathrm{L}$ and $0.1 \mathrm{~Bq} / \mathrm{L}$ for total beta and total alpha radioactivity, respectively (EU Council
Directive 2013/51/EURATOM). With the installation of mine water treatment stations by former mines in the Mondego catchment basin, radioactivity levels in surface waters decreased further over the most recent years. For example, at the stream Ribeira do Castelo, near the Cunha Baixa mine (Mangualde), radionuclide concentrations were at very high values years ago, as in Ribeira da Pantanha (Fig. 2) and with the installation of a mine water treatment station, values currently dropped to near natural background levels.

Table 1. Comparison of radioactivity concentrations and ambient radiation doses before and after environmental remediation at several uranium legacy sites in Portugal

\begin{tabular}{|c|c|c|c|}
\hline Site description & Before remediation & After remediation & Remediation work \\
\hline $\begin{array}{l}\text { Ambient dose rate } 1 \mathrm{~m} \text { above ground } \\
\text { on milling tailings (Forte Velho) }\end{array}$ & $\begin{array}{l}\text { (year 2014) } \\
9.5 \mu \mathrm{Sv} / \mathrm{h}\end{array}$ & $\begin{array}{l}\text { (year 2016) } \\
1 \mu \mathrm{Sv} / \mathrm{h}\end{array}$ & $\begin{array}{l}\text { Removal of tailings } \\
\text { materials }\end{array}$ \\
\hline $\begin{array}{l}\text { Ambient dose rate } 1 \mathrm{~m} \text { above ground } \\
\text { on milling tailings (Urgeiriça) }\end{array}$ & $\begin{array}{l}\text { (year 2003) } \\
7.5 \mu \mathrm{Sv} / \mathrm{h}\end{array}$ & $\begin{array}{l}\text { (year 2010) } \\
0.35 \mu \mathrm{Sv} / \mathrm{h}\end{array}$ & Tailings cover \\
\hline $\begin{array}{l}\text { Average outdoor radon in surface air } \\
\text { near uranium milling tailings } \\
\text { (Urgeiriça) }\end{array}$ & $\begin{array}{l}\text { (year 2004) } \\
440 \mathrm{~Bq} / \mathrm{m}^{3}\end{array}$ & $\begin{array}{l}\text { (year 2015) } \\
40 \mathrm{~Bq} / \mathrm{m}^{3}\end{array}$ & Tailings cover \\
\hline $\begin{array}{l}\text { Radionuclides dissolved in water of } \\
\text { stream R. Pantanha (near Urgeiriça) }\end{array}$ & $\begin{array}{l}\text { (year 2004) } \\
\mathrm{mBq} / \mathrm{L} \\
{ }^{238} \mathrm{U}:(3 \pm 1) \times 10^{5} \\
{ }^{226} \mathrm{Ra}: 100 \pm 3 \\
{ }^{210} \mathrm{~Pb}: 176 \pm 9\end{array}$ & $\begin{array}{l}\text { (Year 2015) } \\
\mathrm{mBq} / \mathrm{L} \\
\\
{ }^{238} \mathrm{U}: 600 \pm 20 \\
{ }^{226} \mathrm{Ra}: 60 \pm 5 \\
{ }^{210} \mathrm{~Pb}: 26 \pm 1\end{array}$ & $\begin{array}{l}\text { Installation of mine } \\
\text { water treatment station }\end{array}$ \\
\hline $\begin{array}{l}\text { Groundwater from a farm well, } \\
\text { Cunha Baixa }\end{array}$ & $\begin{array}{l}\text { (year 2007) } \\
\mathrm{mBq} / \mathrm{L} \\
\\
{ }^{238} \mathrm{U}: 4176 \pm 280 \\
{ }^{226} \mathrm{Ra}: 184 \pm 40 \\
\left.{ }^{210} \mathrm{~Pb}: 51 \pm 7\right)\end{array}$ & $\begin{array}{l}\text { (year 2014) } \\
\mathrm{mBq} / \mathrm{L} \\
\\
{ }^{238} \mathrm{U}: 1640 \pm 80 \\
{ }^{226} \mathrm{Ra}: 340 \pm 20 \\
{ }^{210} \mathrm{~Pb}: 4.8 \pm 0.3\end{array}$ & $\begin{array}{l}\text { Continued pumping and } \\
\text { neutralization of water } \\
\text { from the underground } \\
\text { mine }\end{array}$ \\
\hline
\end{tabular}

Radioactivity in vegetables and fruits from kitchen garden productions for family consumption were also determined in several areas. For example, radionuclides in products from Urgeiriça were consistently higher than from comparison sites within the region [10]. This radioactivity enhancement was due to agriculture in contaminated soils and especially to irrigation with mine water or well water contaminated by mine seepage $[14,15]$.

Exposure to radon was assessed in the neighborhood of uncovered milling waste piles at Urgeiriça, and results showed that outdoor radon $\left({ }^{222} \mathrm{Rn}\right)$ in surface air by the nearest houses was enhanced up to $400-600 \mathrm{~Bq} / \mathrm{m}^{3}$ when the breeze was blowing from the waste piles, but dropped to values under $50 \mathrm{~Bq} / \mathrm{m}^{3}$ when the breeze was blowing in the opposite direction.

Assessment of radiation exposure of individuals in families living in the most exposed areas, for example in Cunha Baixa village, indicated that radionuclide ingestion with vegetables from their own production could exceed the limit of $1 \mathrm{mSv} /$ year on top of exposure to natural background [8]. Altogether, taking into account the outdoor radon exposure plus water and local food consumption, the effective radiation dose rate for the most exposed individuals exceeded the annual dose limit of $1 \mathrm{mSv} / \mathrm{y}$ and could attain 4-5 $\mathrm{mSv} /$ year above radiation background. Moreover, if the construction of buildings for residences or workplaces would take place on the tailing heaps, than the external exposure could jump up to $32 \mathrm{mSv} / \mathrm{y}$ for external radiation only, due high concentrations of uranium daughters in milling waste materials [13-20].

\section{ENVIRONMENTAL REMEDIATION AND REDUCTION OF RADIATION EXPOSURE}

The risk of exposure to enhanced radiation for the people living in several areas near old uranium mines with mining and milling waste was considered not acceptable under the radiation protection standards established by the EU Directive 59/2013 and it was not in agreement also with both the older standards of EU Directive 29/1996 and IAEA international Basic Safety Standards [21].

An environmental remediation programme for legacy mine areas (radioactive and non-radioactive) was approved by the Government and entrusted to the mine holding EDM, a former State owned uranium 
F. P. Carvalho, Uranium mining legacy and radiation protection, Rad. Applic., 2018, 3, 1, 1-6

mining company. Remediation works started in 2005 and have encompassed, up to the present, more than 70 old and abandoned mine sites from a total of 145 , including 60 radium-uranium mining sites.

As part of the remediation works, milling waste piles were relocated, re-shaped to stabilize the slopes, and covered with a multi-layer cap (Figure 3). The cover prevents waste weathering and material dispersal and, furthermore, it prevents radon emanation and gamma (ambient) radiation. Mine water treatment stations were modernized or newly installed at several mines to treat contaminated mine drainage and reduced the discharge of radionuclides into surface streams. The removal of the contaminated upper soil layer and especially the closure of contaminated wells used for irrigation and their replacement with a supply of clean water allowed for the reduction of contaminated horticulture products and radiation exposure through the ingestion of local agriculture products.

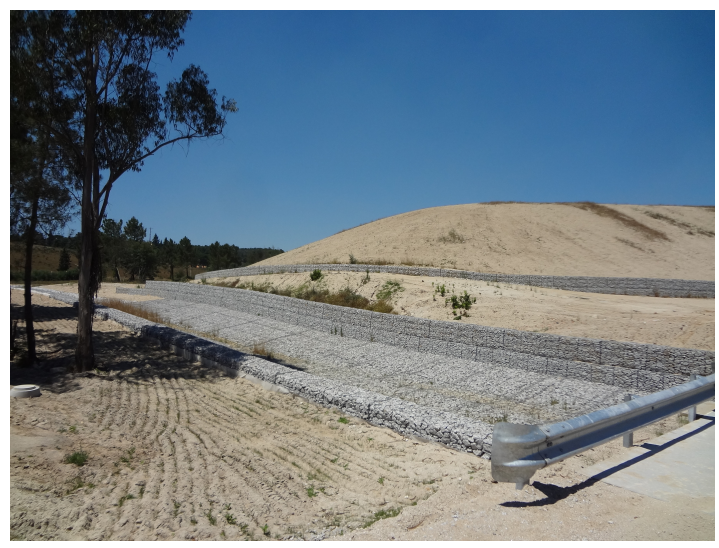

Figure 3. Milling tailings with the cover in place, at Urgeiriça. In the first plane, the stream Ribeira da Pantanha after clean up and reconstruction of the stream bed.

Table 1 gives a summary for several parameters before and after implementation of radiation protection and environmental remediation measures. It can be observed that external (ambient) radiation was reduced to background values, radionuclide concentrations in surface water streams receiving mine discharges were reduced to values close to natural background, and radon in outdoor surface air near waste piles dropped to background values $[18,19]$.

Contamination of groundwater by radioactive mine seepage, which occurred in a few places such as by the mine of Cunha Baixa, is however a different and resilient process. Natural attenuation of this radioactive contamination has not been significant in the last 15 years and remained nearly at the same level. Wells in this area were, therefore, closed and the population is supplied nowadays with water from the Dão River, from outside the contaminated area. This water supply made available for human consumption and irrigation displays radioactivity content at the regional background values.

\section{RADON EXPOSURE AND RADIATION PROTECTION OF THE PUBLIC}

High radon concentrations in houses and other buildings in the uranium bearing region are more difficult to abate and remain an issue of concern. In worldwide average, radon alone accounts for about $50 \%$ of average human exposure to ionizing radiation, i.e. with about $1.2 \mathrm{mSv} / \mathrm{y}$ to the average annual exposure of $2.4 \mathrm{mSv} / \mathrm{y}$ [21]. In uranium bearing regions, with many small mineralizations of uranium formed in granite fractures and with legacy uranium mining and milling facilities, radon is generally more elevated than elsewhere, contributing to exposures with higher doses [23].

Screening for radon concentrations in houses of these regions has shown that radon indoors may display a wide range of concentrations, from average values under $100 \mathrm{~Bq} / \mathrm{m}^{3}$ up to 12 ooo $\mathrm{Bq} / \mathrm{m}^{3}$. Some houses were identified as of enhanced indoor radon concentrations because of the use of mine materials in the construction. Radon countermeasures in such cases may involve the spotting of radioactive materials in the house walls and their removal. However, other houses display high radon concentrations that do not originate in construction materials and, instead, originate in from the natural ground under the construction. In houses built over fractures in granites with uranium vein deposits, radon may accumulate to high concentrations indoors. Radon exposure of the population, therefore, is not in every case directly related to mining activities.

Correlation between radon exposure (based on average indoor radon) and lung cancer was statistically verified in Portugal and higher lung cancer incidence was observed in regions bearing higher natural radiation background where, actually, most old radium and uranium mines are located. To abate exposure to higher radon concentrations, the WHO recommendations for implementation of national radon action plans seem very relevant and directly applicable [22].

\section{CONCLUSIONS}

Old uranium mining areas and milling facilities, that were in activity during most of the $20^{\text {th }}$ century displayed radioactive contamination and enhanced radiation levels. In several of these uranium legacy areas, radiation exposure of members of the public living in their vicinity exceeded the radiation dose limit of $1 \mathrm{mSv}$ /year above natural radiation background. Site clean-up and environmental remediation measures were implemented since 2005. These remediation works, that in some cases configure intervention such as defined in the EU Directive 59/2013, were able to confine radioactive materials (tailings), abate ambient radiation exposure, and control or eliminate radionuclide transfer pathways leading to humans. Appropriate measures to treat radioactive mine drainage and to prevent radioactive discharges into surface waters were effective in reducing contamination of surface water streams. However, in a few sites where contamination of groundwater 
F. P. Carvalho, Uranium mining legacy and radiation protection, Rad. Applic., 2018, 3, 1, 1-6

occurred, the radioactive contamination of such resource may take many years to be solved.

Together with contaminated groundwater and acid mine drainage, radon in dwellings of uranium bearing regions is the major radiation source to the public. In some cases, radon is related to mining activities, but in many buildings radon originates in the natural and unmodified occurrence of uranium in the ground. Regardless of the origin of indoor radon, it still remains the main contributor to the radiation dose received by humans. Due to the established correlation between radon exposure in dwellings and lung cancer, a national action plan for radon must be developed in Portugal to manage and reduce radiation exposure to this radioactive gas, with a priority to uranium bearing regions.

Investigation of radioactivity in uranium legacy areas followed by intervention for environmental remediation works could abate radiation exposure and provide enhanced radiation protection to the population. However, instead of a reactive post-mining strategy, every new uranium mining project shall take the radiation protection issues into account and implement proper radiation safety management during the entire life cycle of the mine in order to ensure radiation protection of the population and environment.

\section{REFERENCES}

1. Environmental Contamination from Uranium Production Facilities and their Remediation. Proceedings of an International Workshop, Proceedings of an International workshop, IAEA, Vienna, Austria, 2005. Retrieved from: https://www-

pub.iaea.org/MTCD/Publications/PDF/Pub1228 web. pdf;

Retrieved on: Jan. 20, 2018

2. R. Hähne, S. Murphy, J. J. Vrijen, "State and prospects of closure and remediation of tailings deposits from uranium ore processing and heap leaching in Europe," in The Uranium Mining Remediation Exchange Group: Selected Papers 1995-2007, Vienna, Austria:

IAEA, 2011, pp. 7 - 27.

Retrieved from: https://www-

pub.iaea.org/MTCD/Publications/PDF/P $1524 \mathrm{CD} / \mathrm{P}$

DF/STI_PUB 1431.pdf;

Retrieved on: Jan. 10, 2018

3. Managing Environmental and Health Impacts of Uranium Mining, No. 7062, OECD NEA, BoulogneBillancourt, France, 2014

Retrieved from: https://www.oecdnea.org/ndd/pubs/2014/7062-mehium.pdf; Retrieved on: Jan. 10, 2018

4. F. P. Carvalho, "Past uranium mining in Portugal: legacy, environmental remediation and radioactivity Monitoring," in The Uranium Mining Remediation Exchange Group: Selected Papers 1995-2007, Vienna, Austria: IAEA, 2011, pp. $145-155$.

Retrieved from: https://wwwpub.iaea.org/MTCD/Publications/PDF/P $1524 \mathrm{CD} / \mathrm{P}$ DF/STI PUB 1431.pdf; Retrieved on: Jan. 10, 2018

5. F. P. Carvalho, "Environmental Radioactive Impact Associated to Uranium Production," Am. J. Environ. Sci. vol. 7, no. 6, pp. 547 - 553, 2011. DOI: 10.3844/ajessp.2011.547.553
6. J. M. Falcão et al., Minas de Uranio e seus Resíduos: Efeitos na Saúde da População, Relatório Científico I, Instituto Superior Técnico, Lisboa, Portugal, 2005. (J. M. Falcão et al., "Uranium mines and their residues: Effects on the public health," Scientific Report I, Institute of technology, Lisbon, Portigal, 2005.)

Retrieved from: http://www.itn.pt/docum/relat/minur ar/2005-MinUrar-relatorio1.pdf Retrieved on: Jan. 10, 2018

7. J. M. Falcão et al., "Minas de Uranio e seus Resíduos: Efeitos na Saúde da População," Relatório Científico II, Instituto Superior Técnico, Lisboa, Portugal, 2007. (J. M. Falcão et al., "Uranium Mines and their residues: Effects on the public heath," Scientific Report II, Institute of technology, Lisbon, Portugal, 2007.) Retrieved from: http://www.itn.pt/docum/relat/minur ar/2007-MinUrar-relatorio2.pdf; Retrieved on: Jan. 11, 2018

8. F. P. Carvalho, "The National Radioactivity Monitoring Program for the Regions of Uranium Mines and Uranium Legacy Sites in Portugal," Procedia Earth Planet. Sci., vol. 8, pp. 33 - 37, 2014 DOI: 10.1016/j.proeps.2014.05.008

9. A herança das minas abandonadas, Lisboa, Portugal: DGEG \& EDM, 2011. (The legacy of abandoned mines, Lisboa, Portugal: DGEG \& EDM, 2011.)

Retrieved from: http://edm.pt/wpcontent/uploads/2017/03/livro edm.pdf; Retrieved on: Jan 11, 2018

10. F. P. Carvalho, J. M. Oliveira, M. Malta, "Analyses of radionuclides in soil, water and agriculture products near the Urgeiriça uranium mine in Portugal," J. Radioanal. Nucl. Chem., vol. 281, no. 3, pp. $479-$ 484, Sep. 2009.

DOI: 10.1007/s10967-009-0027-5

11. F. P. Carvalho et al., "Radioactive survey in former uranium mining areas in Portugal," in Proc. International Workshop on Environmental Contamination from Uranium Production Facilities and Remediation Measures, Lisbon, Portugal, 2004, pp. $11-13$.

Retrieved from: https://www-

pub.iaea.org/MTCD/Publications/PDF/Pub1228 web. pdf;

Retrieved on: Jan. 11, 2018

12. F. P. Carvalho et al., "Contamination of hydrographical basins in uranium mining areas of Portugal," in Uranium in the Environment: Mining Impacts and Consequences, B. J. Merkel, A. Hasche-Berge, Eds., Berlin, Germany: Springer-Verlag, 2006, ch. 70, pp. $691-702$. DOI: $10.1007 / 3-540-28367-6 \_70$

13. F. P. Carvalho, J. M. Oliveira, I. Faria, "Alpha Emitting Radionuclides in Drainage from Quinta do Bispo and Cunha Baixa Uranium Mines (Portugal) and Associated Radiotoxicological Risk," Bull. Environ. Contam. Toxicol., vol. 83, no. 5, pp. 668 - 673, Nov. 2009.

DOI: 10.1007/s00128-009-9808-3 PMid: 19590808

14. F. P. Carvalho, J. M. Oliveira, M. O. Neves, M. M. Abreu, E. M. Vicente, "Soil to plant (Solanum tuberosum L.) radionuclide transfer in the vicinity of an old uranium mine," Geochem. Explor. Env. A, vol. 9, no. 3, pp. $275-278,2009$. DOI: $10.1144 / 1467-7873 / 09-213$

15. F. P. Carvalho, J. M. Oliveira, M. Malta, "Radioactivity in Soils and Vegetables from Uranium Mining Regions," Procedia Earth Planet. Sci., vol. 8, pp. $38-42,2014$

DOI: 10.1016/j.proeps.2014.05.009

16. F. P. Carvalho, J. M. Oliveira, M. Malta, "Intake of Radionuclides with the Diet in Uranium Mining Areas," Procedia Earth Planet. Sci., vol. 8, pp. 43 - 47, 2014. 
F. P. Carvalho, Uranium mining legacy and radiation protection, Rad. Applic., 2018, 3, 1, 1-6

DOI: 10.1016/j.proeps.2014.05.010

17. F. P. Carvalho, J. M. Oliveira, M. Malta, "Radioactivity in Iberian Rivers with Uranium Mining Activities in their Catchment Areas," Procedia Earth Planet. Sci., vol. 8, pp. $48-52,2014$

DOI: $10.1016 /$ j.proeps.2014.05.011

18. F. P. Carvalho et al., "Radioactivity in the environment around past radium and uranium mining sites of Portugal," J. Environ. Radioact., vol. 96, no. 1-3, pp. 39 - 46, Jul-Sep. 2007.

DOI: 10.1016/j.jenvrad.2007.01.016 PMid: 17433852

19. F. P. Carvalho, J. M. Oliveira, M. Malta, "Radioactivity and Water Quality in Areas of Old Uranium Mines (Viseu, Portugal)," Water Air Soil Pollut., vol. 227, no. 8, pp. 227 - 252, Aug. 2016.

DOI: $10.1007 / \mathrm{s} 11270-016-2948-2$

20. F. P. Carvalho, J. M. Oliveira, M. Malta, "Preliminary assessment of uranium mining legacy and environmental radioactivity levels in Sabugal region, Portugal," Int. J. Energ. Environmental Engineering, vol. 7, no. 4, pp. 399 - 408, Dec. 2016.

DOI: $10.1007 / \mathrm{s} 40095-016-0219-\mathrm{Z}$

21. Radiation protection and safety of radiation sources: international basic safety standards, General Safety Requirements No. GSR Part 3, IAEA, Vienna, Austria, 2014.
Retrieved from: https://www-

pub.iaea.org/mtcd/publications/pdf/pub1578 web57265295.pdf;

Retrieved on: Jan. 11, 2018

22. Sources and effects of ionizing radiation, vol. 1, UNSCEAR Report (A/55/46), UNSCEAR, New York (NY), USA, 2000.

Retrieved from: http://www.unscear.org/docs/publicat ions/2000/UNSCEAR 2000 Report Vol.I.pdf;

Retrieved on: Jan. 12, 2017

23. F. P. Carvalho, J. M. Oliveira, M. Malta "Radon in a uranium bearing region of Portugal," in Book of Abstr. $5^{\text {th }}$ Int. Conf. Radiation and Applications in Various Fields of research (RAD 2017), Budva, Montenegro, 2017, p. 452.

Retrieved from: http://www.radconference.org/helper/download.php?file=../pdf/Book \%200f\%20Abstracts\%20RAD\%202017.pdf;

Retrieved on: Jan. 15, 2018

24. WHO handbook on indoor radon: a public health perspective, WN 615, WHO, Geneva, Switzerland, 2009.

Retrieved from: http://apps.who.int/iris/bitstream/106 6.5/44149/1/9789241547673 eng.pdf;

Retrieved on: Jan. 12, 2017 